\title{
Quantitative Research of Systematic and Functional Microbial Groups Associated with Decaying Solid Green Household Waste in Water and Soil
}

\author{
Azeddin El Barnossi*, Fatimazahrae Moussaid, Abdelilah Iraqi Housseini \\ Biotechnology Laboratory, Faculty of Sciences Dhar El Mahraz, Sidi Mohammed Ben Abdellah University, \\ Fez-Atlas, Morocco
}

Received: 13 April 2019

Accepted: 15 September 2019

\begin{abstract}
Several research studies have focused on microbiological studies of waste in the case of composts and vermicompost. However, until now systematic and functional analyses of the microbial groups of separately decaying green household waste in the natural environment have been unsatisfactory. Therefore, in our previous studies, the systematic and functional microbial groups associated with decaying pomegranate and banana wastes in water and soil have been well characterized. The quantitative results of the systematic groups (bacteria, yeasts, molds and actinomycetes) have shown that the values of these microbial groups were generally lower in banana waste than in pomegranate waste, and higher in soil decay than in water decay. The quantitative results of the functional groups have shown that amylolytics were highest $\left(6.410^{7}\right.$ cells/g dw) after 15 days, nitrifiers were most pronounced $\left(8.5610^{6} \mathrm{cells} / \mathrm{g} \mathrm{dw}\right)$ after 30 days, denitrifiers were important (3.63 $10^{5}$ cells $\left./ g \mathrm{dw}\right)$ after 60 days, aerobic nitrogen fixers were highest $\left(3.7810^{9}\right.$ cells $\left./ \mathrm{g} \mathrm{dw}\right)$ after 75 days, and ammonifiers were most noticeable (3.9 $10^{8}$ cells/g dw) after 90 days of decay.
\end{abstract}

Keywords: waste, decay, systematic groups, functional groups, recovery

\section{Introduction}

Currently, solid household waste worldwide is increasing as a result of population growth, changing production and consumption patterns [1-3]. This waste can cause a global problem due to its adverse effects on human health and the environment $[1,4,5]$. At

*e-mail: azeddin.elbarnossi@usmba.ac.ma the international level and especially in developing countries, biodegradable solid wastes are being used in agriculture as a bioresource through their environmental and economic benefits $[6,7]$.

Several research studies have focused on microbiological studies of household waste in the case of compost and vermicompost [8-10]. However, until now systematic and functional analyses of microbial groups of decaying green household waste in water and soil have been unsatisfactory [11]. Household 
biodegradable waste after its release into an aquatic or terrestrial ecosystem is decomposed by the intervention of several biological and physicochemical factors [3].

The research that has been carried out on the study of green household waste has been focused on the study of heterogeneous mixtures of those wastes, and the microbiological study of those wastes remains unsatisfactory. We studied the systematic and functional microbial groups of two green household wastes (banana and pomegranate wastes) separately decomposed in water and soil, the purpose of which is to provide new information on the microbiology of decomposed green household wastes in the natural environment and to propose a new method for recovering these wastes and the products resulting from their degradation.

\section{Materials and Methods}

\section{Biological Material}

Two types of green household waste were used (banana and pomegranate waste) that were collected from fruit juice producers. This fresh waste was placed in 20-1 buckets. $50 \mathrm{~g}$ of each waste was cut into pieces and placed in net bags [3], and then in buckets - half of which were filled with 151 of spring water and the other half with $15 \mathrm{~kg}$ of soil from the garden of the Faculty of Sciences Dhar Mahraz, Fez, Morocco. For each waste, the decay was carried out in triplicate. The decomposed waste in the soil was irrigated every 5 days with 11 of sterile spring water during the study period to avoid desiccation of the samples and maintain a moisture level close to saturation [3].

\section{Preparing the Homogenates}

Samples were taken every 15 days of the study period (between March and June 2018) [3]. A sample of $10 \mathrm{~g}$ was cut with a sterile scissors, and then ground in an amount of sterile spring water. The grinding was carried out with a rotary knife mill five times for a period of one minute with 10 -second intervals under aseptic conditions [3]. The suspension was then shaken for $2 \mathrm{~h}$ in order to release as much microbial load as possible [12].

\section{Study of Systematic Groups}

The culture media used for the counting of the systematic groups was elective media modified by enrichment with $7 \%(\mathrm{v} / \mathrm{v})$ waste extract and using spring water. The abundance of total bacteria, molds, yeasts and actinomycetes was estimated on their respective media: bacterial media [12], agar malt media, YPG (yeast, peptone and glucose) media, and media that was used by Kumar and Jadeja [13]. The microorganism count was carried out by the suspension-dilution method [12]. Thus, in three repetitions, $0.1 \mathrm{ml}$ of each dilution $\left(10^{-1}\right.$ to $\left.10^{-8}\right)$ was separately deposited in the middle in each of three petri dishes $90 \mathrm{~mm}$ in diameter. After surface spreading and incubation at $28^{\circ} \mathrm{C}$ for 7 days, the colonies that appeared were counted for each dilution, then the average number of CFUs (colony forming units) per $\mathrm{g} \mathrm{dw}$ (gram dry weight) was calculated for each waste $[10,14]$.

\section{Study of Functional Groups}

For the quantification of functional groups, $1 \mathrm{ml}$ in three repetitions of each dilution $\left(10^{-1}\right.$ to $10^{-8}$ ) corresponding to each type of digested waste in water and soil were separately added to the tubes containing the culture media used for the enumeration of amylolytics, aerobic nitrogen fixers, ammonifiers, denitrifiers, and nitrifiers according to [15-18]. After seeding, the tubes were incubated at $28^{\circ} \mathrm{C}$ in darkness for 7 days. The determination of microbial load was done by determining the most probable number of germs (MPN) using the Mac Crady table [19].

\section{Statistical Analysis}

The results reported in this study were means of the three replicates. Our results were designed and processed using GraphPad prism 5 software. The statistical processing of the results obtained were carried out using the SPSS 20 software according to a mean analysis (Student t-test) and an analysis of variance (ANOVA I) [3].

\section{Results and Discussion}

\section{Systematic Groups}

\section{Total Bacteria}

The variation of total bacteria during the decay process of pomegranate and banana wastes in water and soil (Fig. 1) has shown that the density of this microbial group was low at the beginning of the decay of these wastes. Then it was gradually increased to a maximum of $4.7410^{10}$ and $3.1510^{10} \mathrm{CFU} / \mathrm{g}$ dw for decaying banana waste in water and soil respectively and a maximum of $6.7210^{10}$ and $9.1610^{10} \mathrm{CFU} / \mathrm{g} \mathrm{dw}$ for decaying pomegranate waste in water and soil respectively. The great heterogeneity of the results of the quantification of total bacteria obtained during our study varies according to the medium and the nature of the substrate. The variation in bacterial communities during our study may be mainly attributable to environmental parameters, as was previously indicated by the work of Zhang et al. [20] and Huang et al. [21]. Our result is consistent with the study by DiazRavifia et al. [22], who showed that composted waste had a high microbial population with densities close to the higher values given for many soils. In their study, 


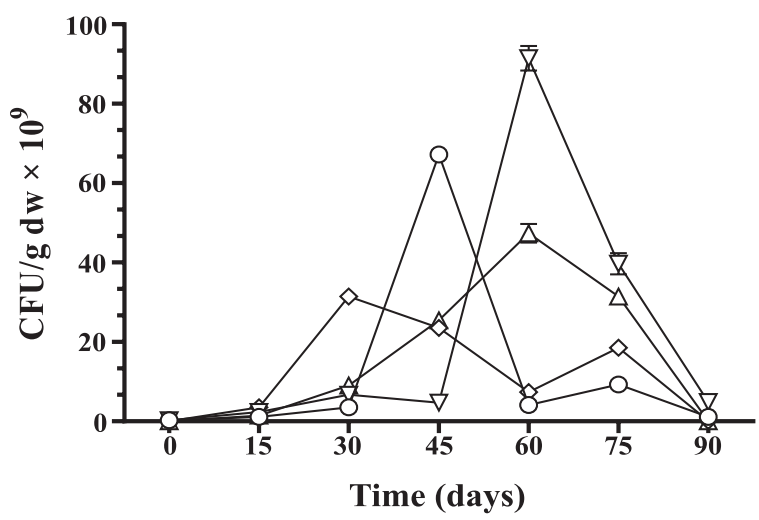

$\triangleleft$ Banana waste/water
$\diamond-$ Banana waste/soil
$\neg-$ Pomegranate waste/soil
$-\circ$ Pomegranate waste/water

Fig. 1. Variation of total bacteria during the decay of banana and pomegranate wastes in water and soil.

Chroni et al. [23] reported an increase in the total number of mesophilic bacteria from $3.210^{6} \mathrm{CFU} / \mathrm{g}$ $\mathrm{dw}$ in the composting of raw bio-wastes to $1.710^{9}$ $\mathrm{CFU} / \mathrm{g} \mathrm{dw}$ at 57 days. Moreover, Ventorino et al. [24] and Van der Heijden et al. [25] have been shown that during the natural biodegradation process of vegetable substrates, the indigenous bacterial community would first develop using more cellulose that is accessible and hemicellulose, and only later would use the more resistant lignin component.

\section{Molds}

The results of the molds count obtained during our study (Fig. 2) showed that this microbial group was present throughout the decay period of banana and pomegranate wastes in water and soil, but with different densities depending on the medium and the waste. The maximum density was in the order of $2.6210^{10}$ and $2.3210^{10} \mathrm{CFU} / \mathrm{g} \mathrm{dw}$ for digested pomegranate waste in water and soil respectively. While it was highest in the order of $6.6110^{9}$ and $7.2810^{9} \mathrm{CFU} / \mathrm{g} \mathrm{dw}$ for banana waste digested in water and soil respectively. In our previous study, the density of molds was reduced after 75 days of decay, which may be due to temperature; several researchers have reported that fungi are inactivated at high temperatures [23]. This variability has been commonly encountered in microbiological studies of natural environments [12]. In general, fungi are known to be the most effective decomposers of vegetable substrates due to their mycelial structure [26]. Our result for the quantification of molds is higher than that obtained by Diaz-Ravifia et al. [22], who showed that the fungi in the studied compost were present in numbers ranging from $10^{5}$ to $10^{8} \mathrm{CFU} / \mathrm{g} \mathrm{dw}$. In addition, Anastasi et al. [27] have also shown fungal load levels ranging from $510^{4}$ to $8.210^{5} \mathrm{CFU} / \mathrm{g} \mathrm{dw}$ in a compost

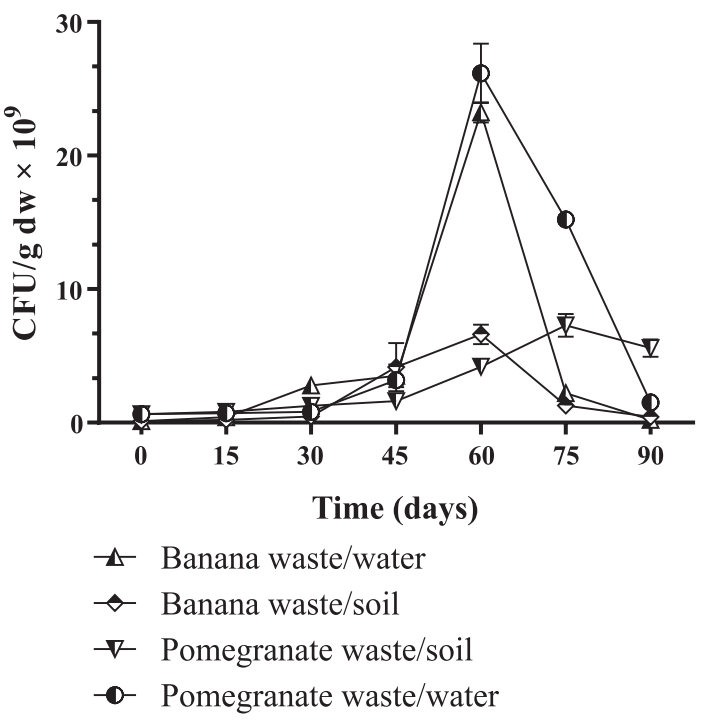

Fig. 2. Mold variations during the decay of banana and pomegranate wastes in water and soil.

and from $5.310^{4}$ to $410^{5} \mathrm{CFU} / \mathrm{g} \mathrm{dw}$ in a vermicompost. In general, the quantitative differences between our results and those in the literature suggest that a given ecological group of microflora corresponds to a given vegetable substrate. This approach has been confirmed by several authors, including Mehta et al. [28], which have been reported to be dominated by mesophilic fungi, such as Aspergillus, Fusarium and Mucor during the later stages of composting. For fungal successions, a decay agent can replace other species when changes in the substrate have interacted with changes in saprophytic competitiveness and inoculum potential, giving it a decisive advantage $[29,30]$.

\section{Yeasts}

The results of the yeast counts (Fig. 3) have shown that this microbial group was formed initially from the degradation of the waste studied by the phyllospheric microflora of the decomposed waste. For banana waste, yeast density reached its maximum (1.37 $10^{10}$ and $\left.4.6810^{9} \mathrm{CFU} / \mathrm{g} \mathrm{dw}\right)$ after 45 days of decay in soil and 75 days of decay in water respectively. For pomegranate waste, the density of yeast was gradually increased to a maximum of about $2.4310^{10} \mathrm{CFU} / \mathrm{g} \mathrm{dw}$ after 45 days of decay in the soil, and $9.410^{9} \mathrm{CFU} / \mathrm{g} \mathrm{dw}$ after 75 days of decay in the water. This variability is probably due to the biotic and abiotic factors associated with decaying wastes [3]. This result was consistent with the one described in the study by Choi and Park [31], who showed that yeast was developed most rapidly, reaching a maximum density of $1.610^{8} \mathrm{CFU} / \mathrm{g} \mathrm{dw}$ of compost from food waste, then rapidly declined and disappeared. In their studies, Chroni et al. [23] have shown that yeasts were present throughout the composting process. Their number dropped from an initial value 


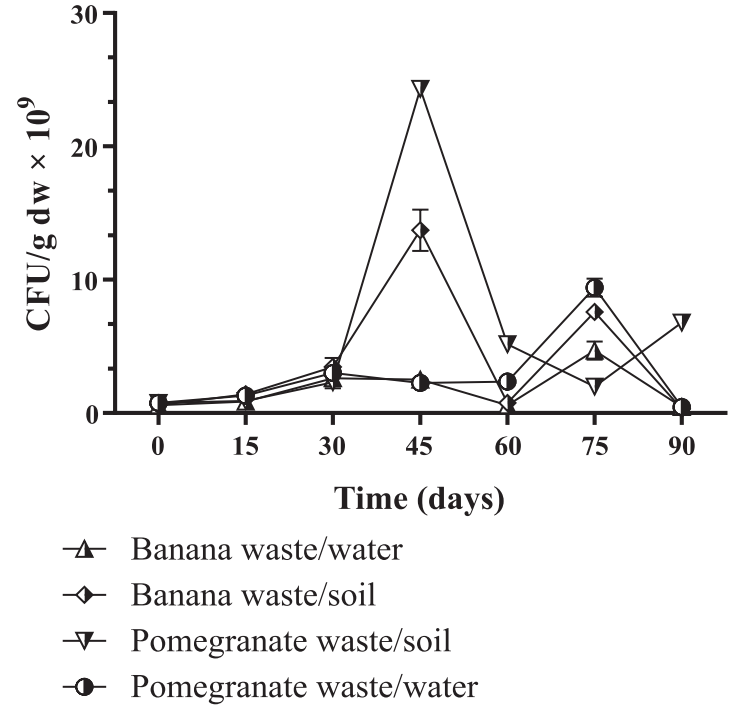

Fig. 3. Variation of yeasts during the decay of banana and pomegranate wastes in water and soil.

of $3.710^{7} \mathrm{CFU} / \mathrm{g}$ dw to $7.810^{4} \mathrm{CFU} / \mathrm{g} \mathrm{dw}$ at 33 days and stabilized at a slightly lower level thereafter. Our results are in agreement with the few studies that have analyzed in detail the succession of these microbial groups [12].

\section{Actinomycetes}

According to our results (Fig. 4), the actinomycetes appeared after 60 days of decay in water and soil for both types of digested wastes in water and soil. After 75 days of decay this microbial group disappeared in the decomposing banana and pomegranate wastes in water, but was maintained at low density $\left(5.5110^{7} \mathrm{CFU} / \mathrm{g} \mathrm{dw}\right)$ in the digested pomegranate waste in the soil. Our study showed that actinomycetes were not predominant in the decay process of banana and pomegranate wastes in water and soil. This may be due to the composition of the substrates studied and to the physicochemical conditions associated with decomposition [3, 23]. Our result is in disagreement with that found by Rana et al. [32] and Aliero et al. [33], who have shown that most actinomycetes are widely distributed in natural habitats such as aquatic and terrestrial habitats. Moreover, Kumar [13] and Rinoy et al. [34] reported that the development of actinomycetes varies according to their mesophilic or thermophilic character, and their ability to degrade available substrates. The absence of actinomycetes at certain states of waste decay was due to physicochemical parameters, Adegboye et al. [35], which reported that environmental factors such as temperature and humidity could affect the distribution of actinomycetes in an environment, support this in the study. Our result conforms with that obtained by DiazRavifia et al. [22], who showed that actinomycetes in compost were present in numbers ranging from $10^{7}$ to $10^{8} \mathrm{CFU} / \mathrm{g} \mathrm{dw}$.

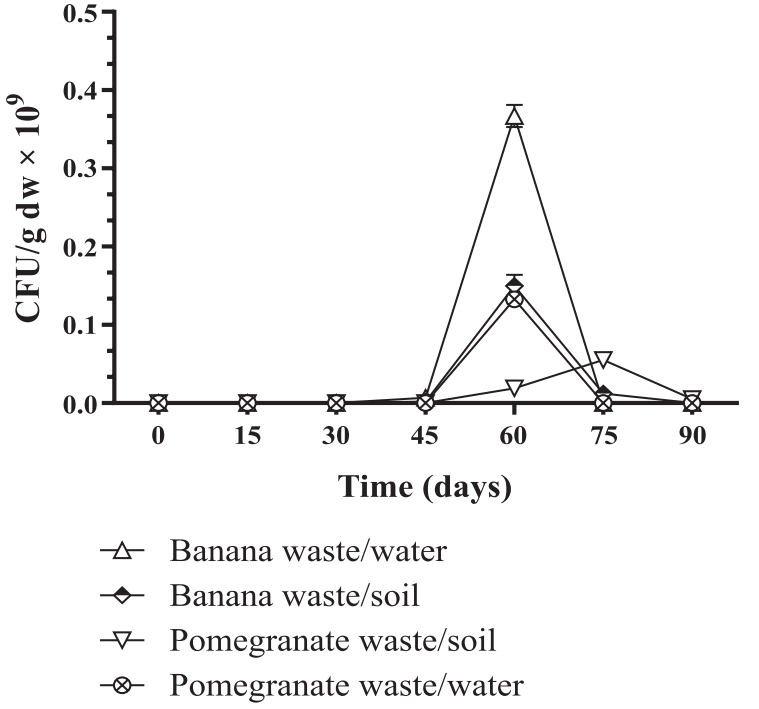

Fig. 4. Variation of actinomycetes during the decay of banana and pomegranate wastes in water and soil.

\section{Functional Groups}

\section{Aerobic Nitrogen Fixers}

Nitrogen fixation is the conversion of atmospheric nitrogen into nitrogen that can be used by plants and animals [36]. It is carried out by certain bacteria that live in the soil or water and succeed in assimilating diatomic nitrogen [16].

Aerobic nitrogen fixatives (Fig. 5) were low during the first three samples of decaying banana waste in water and soil, and decaying pomegranate waste in water. However, this group appeared at the third sampling $\left(9.0510^{5}\right.$ cells/g dw) for decaying pomegranate waste in the soil. After 75 days of decay, aerobic nitrogen fixatives were significant $\left(1.3510^{9}, 3.7810^{9}\right.$ and $2.5510^{9}$ cells $/ g \mathrm{dw}$ ) for banana waste decaying in water and soil and pomegranate waste decaying in soil respectively. Aerobic nitrogen fixatives were low throughout the study period for decaying pomegranate waste in water. Stein and Klotz [37] have shown that biological nitrogen fixation remains an activity exclusively carried out by bacteria; nitrogen fixation is extremely sensitive to oxygen, which requires microorganisms to develop protective mechanisms such as spatial decoupling, temporal decoupling, rapid oxygen respiration, or maximizing nitrogen synthesis and renewal. Several authors in previous studies have shown that $\mathrm{N}_{2}$ binding occurs in three different ways: through geochemical processes [38], biologically through the action of the enzyme azotase found only in a particulate group of microorganisms [39], and industrially through the Haber-Bosch process [40]. In addition, studies by Mirza et al. [41] and Prescott et al. [42] have shown that variations in abiotic and biotic factors influence free-living nitrogen-fixing bacterial communities. 

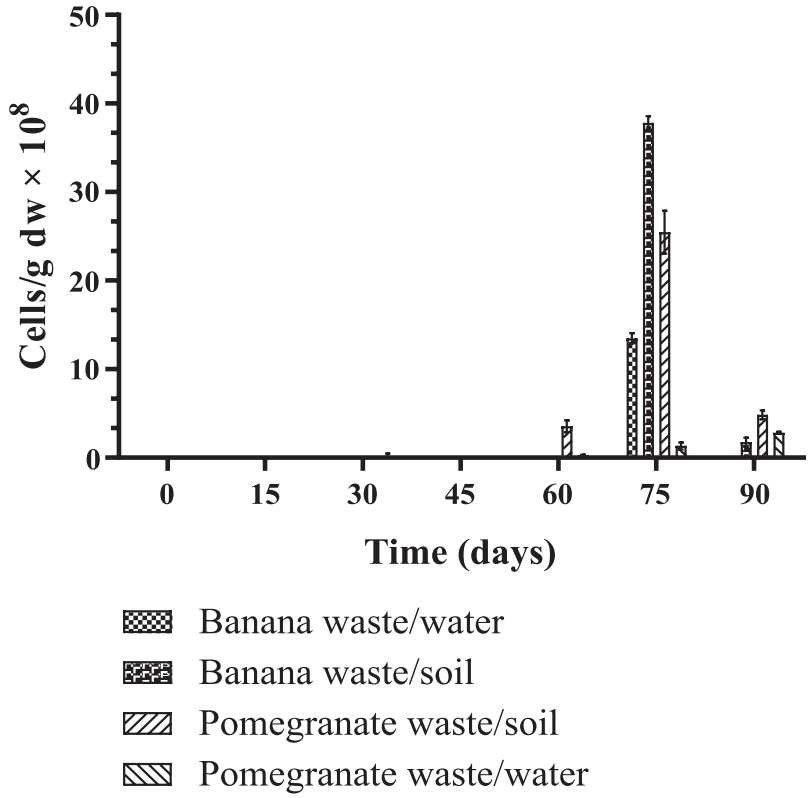

Fig. 5. Variations of aerobic nitrogen fixative during the decay of banana and pomegranate wastes in water and soil.

\section{Ammonifiers}

Ammonification is the transformation of organic nitrogen into ammonium $\left(\mathrm{NH}_{4}^{+}\right)$under the action of heterotrophic microorganisms that use carbon substrates as an energy source [36], a process that is unspecified and performed by a large number of reducing microorganisms, aerobic or anaerobic bacteria, but specialized in the form of the utilization of organic nitrogen [43].

The results of quantifying ammonifiers (Fig. 6) have shown that the density of this microbial group has been low for banana waste decaying in water compared to decay in soil, or also compared to pomegranate waste decomposing in water and in soil. The density of the ammonifiers has been increased to a maximum level of $1.7210^{8}$ and $3.6310^{8}$ cells/g dw after 75 days of decay of banana waste in water and soil respectively. While the density of this group has been increased to a maximum level of $3.5310^{8}$ cells $/ \mathrm{g} \mathrm{dw}$ and $3.910^{8}$ cells $/ \mathrm{g}$ dw after 90 days of decay of pomegranate waste in the soil and water respectively. Stein and Klotz [37] have found that the ammonification is carried out by both bacteria and fungi. The study by Bano et al. [44] has shown that the intensity of ammonification decreases with increasing $\mathrm{pH}$, that it is accepted in vitro that the ammonification is relatively independent of $\mathrm{pH}$, and that it is slightly more active in neutral or alkaline media than in acidic media. In their studies, Yoon et al. [45] have shown that high temperatures and alkaline $\mathrm{pH}$ conditions have led to the predominance of the ammonification process.

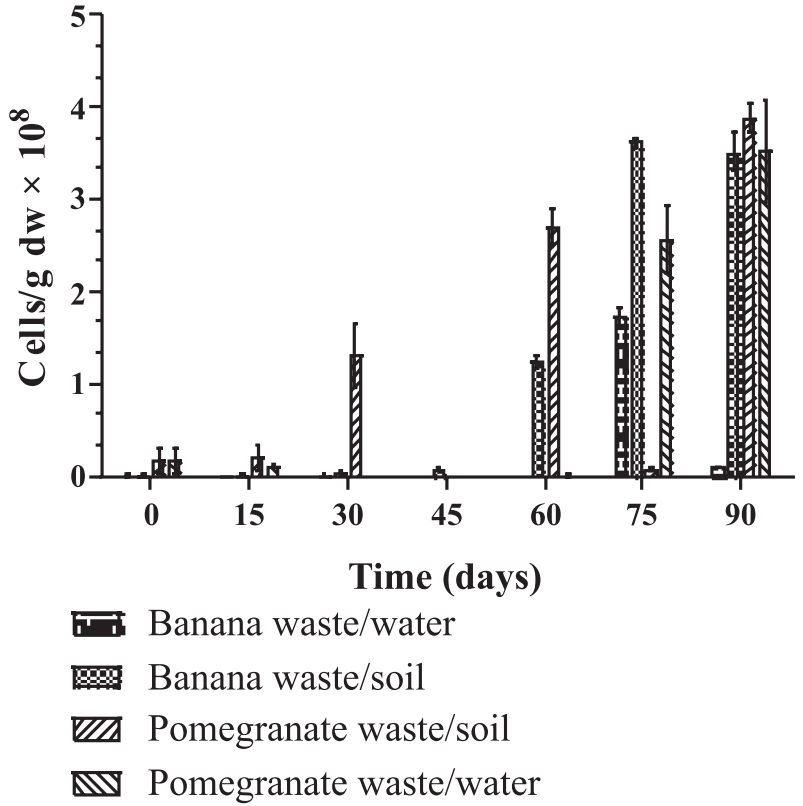

Fig. 6. Variations of ammonifiers during the decay of banana and pomegranate wastes in water and soil.

\section{Nitrifiers}

Nitrification is frequently considered to be the main fate of $\mathrm{NH}_{4}$ in agricultural soil [36], and also the process responsible for the transformation of $\mathrm{NH}_{4}^{+}$into $\mathrm{NO}_{2}{ }^{-}$and $\mathrm{NO}_{3}^{-}$[18].

The quantitative study of nitrifiers (Fig. 7) has shown that this microbial group has been important especially for digested pomegranate waste in water and soil. The maximum nitrifier density was in the order of $8.0710^{6}$ and $8.5610^{6}$ cells/g dw, which was obtained after 30 days of decay of the pomegranate waste in the soil and water respectively. Nevertheless, the density of this group was maximum in the order of $4.0810^{6} \mathrm{cells} / \mathrm{g} \mathrm{dw}$, which was obtained after 45 days of decay of banana waste in water, while the availability of this group was low $\left(0.12810^{6}\right.$ cells $\left./ \mathrm{g} \mathrm{dw}\right)$ for banana waste decaying in water.

The variability of nitrifier results obtained during our study may be due to the nature of the substrate being decomposed and the decay media, on the one hand, and to the physicochemical parameters associated with decomposition on the other hand. This has been confirmed by the study of Durvasula and Rao [46], who have attributed to the decrease in nitrifiers during the decay of organic matter to the inhibition of the growth of nitrifying microorganisms by increasing the temperature, and by the presence of a high concentration of ammonia in the decay medium. In addition, Leys et al. [47] have shown in their study that net nitrification was low despite high concentrations of internal $\mathrm{NH}_{4}$ and ambient $\mathrm{O}_{2}$, but the actual nitrification of the water was very low. 


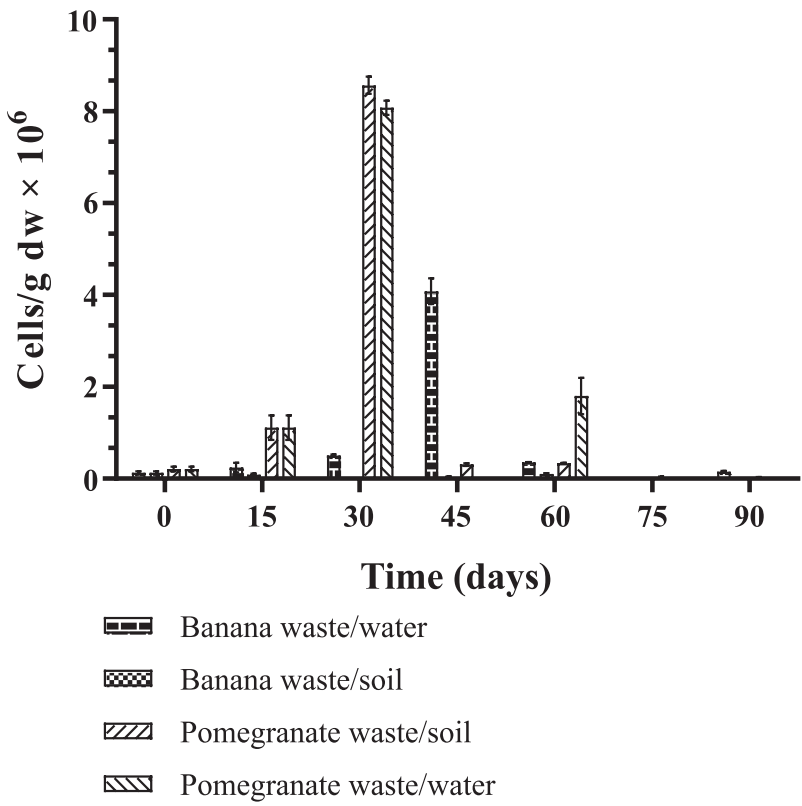

Fig. 7. Variation of nitrifiers during the decay of banana and pomegranate wastes in water and soil.

\section{Denitrifiers}

Denitrification is one of the metabolic processes in the nitrogen cycle [36] through which nitrate is transformed into nitrite, nitrogen monoxide, nitric oxide, or gaseous nitrogen [45]. The quantification of denitrifiers (Fig. 8) has shown that this group has not been predominant in the decay process of banana and pomegranate wastes in water and soil. The denitrifier density was high, with a maximum level of

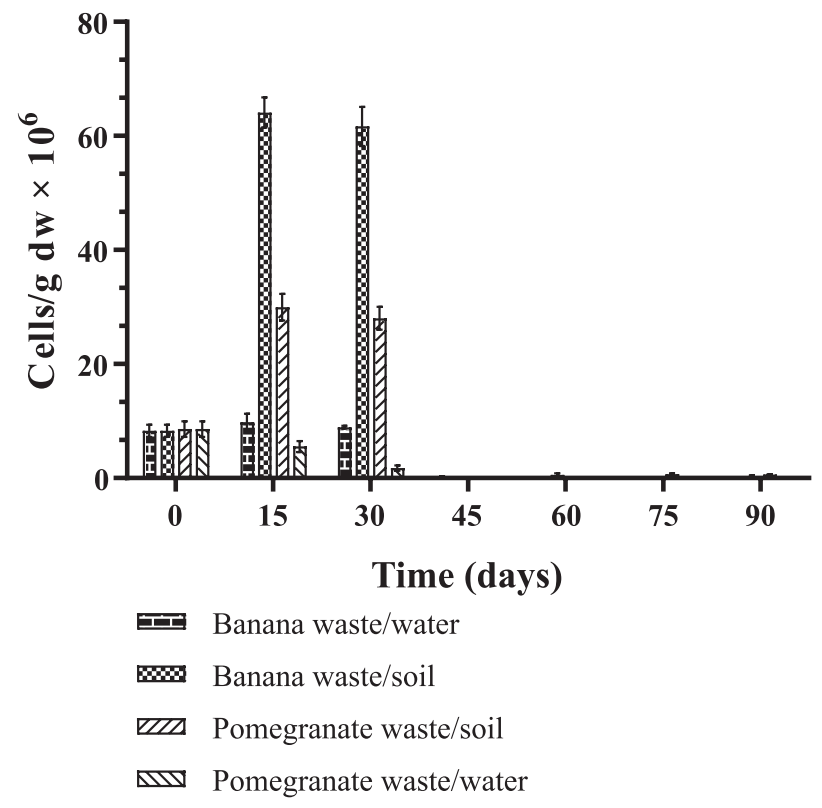

Fig. 9. Variation of amylolytics during the decay of banana and pomegranate wastes in water and soil.

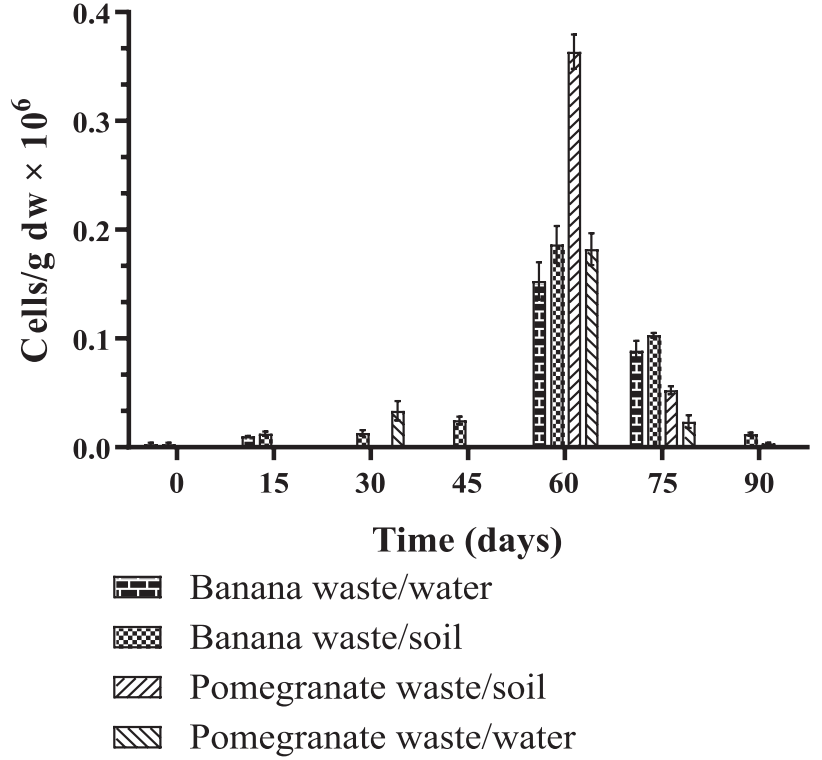

Fig. 8. Variations of denitrifiers during the decay of banana and pomegranate wastes in water and soil.

$3.6310^{5}$ cells $/ \mathrm{g} \mathrm{dw}$ for decaying pomegranate waste in the soil, while the density of this microbial group was low for decaying pomegranate waste in water $\left(1.8210^{5}\right.$ cells/g dw) and decaying banana waste in water and soil $\left(1.5310^{5}\right.$ and $1.8610^{5}$ cells $\left./ \mathrm{g} \mathrm{dw}\right)$ respectively.

The low denitrifiers density found during the decay of banana and pomegranate wastes in water and soil may be due to the presence of sufficient aeration conditions in accordance with $\mathrm{He}$ et al. [48], which have shown that the presence of sufficient aeration conditions results in a decrease in denitrification, because denitrification is carried out under anaerobic conditions $[49,50]$, which has shown that the denitrification rate decreases when the $\mathrm{pH}$ is low.

\section{Amylolytics}

The amylolytics are microorganisms that produce amylases [51], which are important hydrolase enzymes that can hydrolyze glycosidic bonds in starch, and break them down into polymers composed of glucose [52].

The study of the variation of amylolytics during the decay process of pomegranate and banana wastes in water and soil (Fig. 9) has shown that this microbial group was important during the first stage of digestion banana and pomegranate wastes in water and soil. Then the density of this group was drastically reduced for both types of decaying waste in water and soil. The decrease in amylolytics during the decay process of banana and pomegranate wastes may be due to physicochemical factors such as increased $\mathrm{pH}$ and decreased starch concentration in the substrate. In accordance with our study, Belbis [53] has shown that amylolytics have less adaptability to substrate changes, both qualitatively and quantitatively. In addition, low 
$\mathrm{pH}(<6)$ promotes the development of amylolytics. Our result has been deferred from that obtained by Chroni et al. [23], who have shown that amylolytics have shared similar levels throughout the composting process.

\section{Conclusions}

The novelty of this study is to characterize the different systematic and functional groups that influence the decay process of banana and pomegranate wastes in water and soil. It also provides new information about the microbiology of organic waste decay in the natural environment. In our previous studies, we were able to show that the microbial density associated with banana and pomegranate wastes has been significant. Those microorganisms that have been isolated may be exploited more thoroughly for agricultural, medical, and environmental interests. The monitoring of the functional groups of the decay of banana and pomegranate wastes over time has shown that banana and pomegranate wastes can be used after certain decay times, directly as an organic fertilizer, which improves the physicochemical characteristics of soils, leading to improved crop yields, and for bioremediation of soils and wastewater contaminated with ammonia or nitrate.

\section{Conflict of Interest}

The authors declare no conflict of interest.

\section{Acknowledgements}

We are grateful to the Biotechnology Laboratory of the Dhar El Mahraz Faculty of Science, Sidi Mohamed Ben Abdellah University of Fez Morocco for provided scientific support. We would particularly like to thank all those who have contributed to this study.

\section{References}

1. ABDHAMID K.B., ISHAK M.Y., ABU SAMAH M.A. Analysis of Municipal Solid Waste Generation and Composition at Administrative Building Café in University Putra Malaysia: A Case Study. Pol J Environ Stud. 24, 1969, 2015.

2. GUPTA N., YADAV K.K., KUMAR V. A review on current status of municipal solid waste management in India. J Environ Sci. 37, 206, 2015.

3. EL BARNOSSI A., MOUSSAID F., IRAQI H.A. Decomposition of tangerine and pomegranate wastes in water and soil: characterization of physicochemical parameters and global microbial activities under laboratory conditions. Int J Environ Stud. 76 (3), 456, 2019.

4. SINGH A. Managing the uncertainty problems of municipal solid waste disposal. J Environ Manage. 240, 259, 2019.
5. SHAH G.M., TUFAIL N., RASHID M.I., IMRAN M., MURTAZA B., SAEED F., FAROOQ M.A.U., BAKHAT H.F. Anaerobic degradation of municipal organic waste among others composting techniques improves $\mathrm{N}$ cycling through waste-soil-plant continuum. J Soil Sci Plant Nutr. 17, 529, 2017.

6. GHULAM M.S., TUFAIL N., BAKHAT F.H., IFTIKHAR A., SHAHID M., HAFIZ M.H., WAJID N., WAQAR A., RIZWAN M., DONG R. Composting of municipal solid waste by different methods improved the growth of vegetables and reduced the health risks of cadmium and lead. Environ Sci Pollut R. 26, 5463, 2019.

7. STAROSTKA-PATYK M. Environmental Approach to Managing Defective Products and Waste in the Household Appliances Industry. Pol J Environ Stud. 28, 1, 2019.

8. CERDA A., ARTOLA A., FONT X., BARRENA R., GEA T., SÁNCHEZ A. Composting of food wastes: Status and challenges. Bioresour Technol. 248, 57, 2018.

9. WANG C., ZUO J., CHEN X., XING W., XING L., LI P., LU X., LI C. Microbial community structures in an integrated two-phase anaerobic bioreactor fed by fruit vegetable wastes and wheat straw. J Environ Sci. 26, 2484, 2014.

10. EL BARNOSSI A., MOUSSAID F., IRAQI H.A. Microbiological study of effects of solid organic waste (chicken droppings and sheep manure) decomposed in the soil used for Pisum sativum cultivation. Int J Environ Stud. 2019. https://doi.org/10.1080/00207233.2019.1704116.

11. LIANG Y., HE X., CHEN X., HU Y., SU Y. NitrogenFixing Bacterial Communities Exhibit Strong Spatial Structure along a Slope Gradient in Karst Shrublands Ecosystem. Pol J Environ Stud. 28, 1, 2019.

12. IRAQI H.A. Microbiological and physicochemistry characterization of dead leaves of Populus euramericana decomposing in the Ain El Rhars hydrosystem of the middle atlas of Morocco. PhD thesis in Natural Sciences, Microbial Ecology (Fez, Morocco: Sidi Mohamed Ben Abdellah University, Faculty of Sciences Dhar El Mahraz); 130, 2001.

13. KUMAR R.R., JADEJA V.J. Isolation of Actinomycetes: A Complete Approach. Int J Curr Microbiol App Sci. 5, 606, 2016.

14. MOURIA B., OUAZZANI T.A., DOUIRA A. Isolation and identification of the mycoflora of compost from municipal solid waste. Nature and Technologie. 9, 13, 2013.

15. AMOOZEGAR M.A., MALEKZADEH F., MALIK K.A. Production of amylase by newly isolated moderate halophile, Halobacillus sp. strain MA-2. Microbiol Methods. 52, 353, 2003.

16. NISHIHARA A., MATSURA K., TANK M., MCGLYNN E.S., THIEL V., HARUTA S. Nitrogenase activity in thermophilic chemolithoautotrophic bacteria in the phylum aquificae isolated under nitrogen-Fixing conditions from Nakabusa hot springs. Microbes Environ. 33, 394, 2018.

17. JOSHI B., SINGH S.D., DEVI B.M., PATHAK H., SHARMA D.K., CHAUDHARY A. Effect of elevated temperature on soil microbial activity and nitrogen transformations in wheat crop (Triticum aestivum). Indian J Agr Sci. 87, 167, 2017.

18. LI Y., CHAPMAN J.S., NICOL G.W., YAO H. Nitrification and nitrifiers in acidic soils. Soil Biol and Biochem. 116, 290, 2018.

19. NEMATI M., HAMIDI A., DIZAJ S.M., JAVAHERZADEH V., LOTFIPOUR F. An Overview on 
Novel Microbial Determination Methods in Pharmaceutical and Food Quality Control. Adv Pharm Bull. 6, 301, 2016.

20. ZHANG J.C., ZENG G.M., CHEN Y.N., YU M., YU Z., LI H., YU Y., HUANG H.L. Effects of physicochemical parameters on the bacterial and fungal communities during agricultural waste composting. Bioresour Technol. 102, 2950, 2011.

21. HUANG C., ZENG G., HUANG D., LAI C., XU P., ZHANG C., CHENG M., WAN J., HU L., ZHANG Y. Effect of Phanerochaete chrysosporium inoculation on bacterial community and metal stabilization in leadcontaminated agricultural waste composting. Bioresour Technol. 243, 294, 2017.

22. DIAZ-RAVIFIA M., ACEA M.J., CARBALLAS T. Microbiological Characterization of Four Composted Urban Refuses. Biol Wastes. 30, 89, 1989.

23. CHRONI C., KYRIACOU A., GEORGAKI I., MANIOS T., KOTSOU M., LASARIDI K. Microbial characterization during composting of biowaste. Waste Manag. 29, 1520, 2009.

24. VENTORINO V., ALIBERTI A., FARACO V., ROBERTIELLO A., GIACOBBE S., ERCOLINI D., AMORE A., FAGNANO M., PEPE O. Exploring the microbiota dynamics related to vegetable biomasses degradation and study of lignocellulose degrading bacteria for industrial biotechnological application. Sci Rep. 5, $8161,2015$.

25. VAN DER HEIJDEN M.G.A., BARDGETT R.D., VAN STRAALEN N.M. The unseen majority: soil microbes as drivers of plant diversity and productivity in terrestrial ecosystems. Ecol Lett. 11, 296, 2008.

26. LI H., XU X., CHEN H., ZHANG Y., XU J., WANG J., LU X. Molecular analyses of the functional microbial community in composting by PCR-DGGE targeting the genes of the -glucosidase. Bioresour Technol. 134, 51, 2013.

27. ANASTASI A., VARESE G.C., MARCHISIO V.F. Isolation and identification of fungal communities in compost and vermicompost. Mycologia. 97, 33, 2005.

28. MEHTA C.M., PALNI U., FRANKE-WHITTLE I.H., SHARMA A.K. Compost: Its role, mechanism and impact on reducing soil-borne plant diseases. Waste Manag. 34, 607, 2014.

29. VILANOVA C., PORCAR M. Are multi-omics enough?. Nat Microbiol. 2016. https://oi.org/10.1038/ nmicrobiol.2016.101.

30. JEDIDI I., SOLDEVILLA C., LAHOUAR A., MARÍN P., GONZÁLEZ-JAÉN M.T., SAID S. Mycoflora isolation and molecular characterization of Aspergillus and Fusarium species in Tunisian cereals. Saudi J of Biol Sci. 25, 868, 2018.

31. CHOI M.H., PARK Y.H. The influence of yeast on thermophilic composting of food waste. Lett Appl Microbiol. 26, 175, 1998.

32. RANA S., SALAM M.D. Antimicrobial potential of actinomycetes isolated from soil sample of Punjab, India. J Microbiol Exp. 1, 10, 2014.

33. ALIERO A.A., EMMANUE E., JOSEPHAT M.N., ALIYU S.H., OKECH M.A., ODDA J. Antibacterial Activity of Actinomycetes Isolated from Waste Dump Soil from Western Uganda. Microbiol Res J Int. 21, 1, 2017.

34. RINOY V., NISHAMOL S., SUCHITHRA R., JYOTHY S., MOHAMED H.A. Distribution and antibacterial activity of actinomycetes from shola soils of tropical montane forest in Kerala, South India. J of Env. 1, 93, 2012.

35. ADEGBOYE M.F., BABALOLA O.O. Taxonomy and ecology of antibiotic producing actinomycetes, Review. Afr J of Agric Res. 7, 2255, 2012.

36. CAPON D.G., BRONK D.A., MULHOLLAND M.R., CARPENTER E.J. Nitrogen in the Marine Environment. Chaper 22, $2^{\text {nd }}$ Edition. Academic Press. 1757, 2008. https://doi.org/10.1016/B978-0-12-372522-6.X00011.

37. STEIN L.Y., KLOTZ M.G. The nitrogen cycles. Current Biology. 26, 94, 2016.

38. GRUBER N., GALLOWAY J.N. An Earth-system perspective of the global nitrogen cycle. Nature. 451, 293, 2008.

39. MCGLYNN S.E., BOYD E.S., PETERS J.W., ORPHAN V.J. Classifying the metal dependence of uncharacterized nitrogenases. Front Microbiol. 3, 419, 2013.

40. HOFFMAN B.M., LUKOYANOV D., YANG Z.Y., DEAN D.R., SEEFELDT L.C. Mechanism of Nitrogen Fixation by Nitrogenase: The Next Stage. Chemical Reviews. 114, 4041, 2014.

41. MIRZA B.S., POTISAP C., NÜSSLEIN K., BOHANNAN B.J.M., RODRIGUES J.L.M. Response of free-living nitrogen-fixing microorganisms to land use change in the Amazon rainforest. Appl Environ Microbiol. 80, 281, 2014

42. PRESCOTT C.E., GRAYSTON S.J. Tree species influence on microbial communities in litter and soil: current knowledge and research needs. Forest Ecol Mana. 309, 19, 2013.

43. CANFIELD D.E., KRISTENSEN E., THAMDRUP B. The Nitrogen Cycle. Adv Mar Biol. 48, 205, 2005.

44. BANO G., ISLAM M., DURRANI M.J., GUL S., BANO A., AKHTAR B., MUHAMMAD S. Nitrogen mineralization in semi-arid rangeland: influence of grazing and land use type. Pure Appl Biol. 5, 987, 2016.

45. YOON S., CRUZ-GARCÍA C., SANFORD R., RITALAHTI K.M., LÖFFLER F.E. Denitrification versus respiratory ammonification: environmental controls of two competing dissimilatory $\mathrm{NO}_{3}^{-} / \mathrm{NO}_{2}^{-}$reduction pathways in Shewanella loihica strain PV-4. The ISME Journal. 9, 1093, 2015.

46. DURVASULA R., RAO D.V.S. Extremophiles from biology to biotechnology. In: Denitrification in Extreme Environments (pp 209-226). Taylor \& Francis Group. 486, 2018.

47. LEYS S.P., KAHN A.S., FANG J.K.H., KUTTI T., BANNISTER R.J. Phagocytosis of microbial symbionts balances the carbon and nitrogen budget for the deep-water boreal sponge Geodia barretti. Limnol Oceanogr. 63, 187, 2017.

48. HE Q., CHEN L., ZHANG S., WANG L., LIANG J., XIA W., WANG H., ZHOU J. Simultaneous nitrification, denitrification and phosphorus removal in aerobic granular sequencing batch reactors with high aeration intensity: impact of aeration time. Bioresour Technol. 263, 214, 2018.

49. LYCUS P., BØTHUN K.L., BERGAUST L., SHAPLEIGH J.P., BAKKEN L.R., FROSTEGÅRD Å. Phenotypic and genotypic richness of denitrifiers revealed by a novel isolation strategy. The ISME Journal. 11, 2219, 2017.

50. SANCHEZ-ANDREA I., ROJAS-OJEDA P., AMILS R., SANZ J.L. Screening of anaerobic activities in sediments 
of an acidic environment: Tinto River. Extremophiles. 16, 829, 2012.

51. RODRIGUES E.F., FICANHA A.M.M., DALLAGO R.M., TREICHEL H., REINEHR C.O., MACHADO T.P., COLLA L.M. Production and purification of amylolytic enzymes for saccharification of microalgal biomass. Bioresour Technol. 225, 134, 2017.
52. ROSLAN R., REHAN M.M., KAMARUDIN K.R., NOOR H.M, HUDA-FAUJAN N., RADZI S.M. Isolation and identification of amylolytic bacteria from Ragi. Malays Appl Biol. 47, 83, 2018.

53. BELBIS G.H. Rumen flora origin, composition, evolution, pathophysiological consquences. $\mathrm{PhD}$ thesis. National Veterinary School of Alfort. 150, 2007. 
